\title{
Molecular Cloning and Characterization of Bacillus alvei Thiol-dependent Cytolytic Toxin Expressed in Escherichia coli
}

\author{
By CHRISTIANE GEOFFROY AND JOSEPH E. ALOUF* \\ Unité des Antigènes Bactériens (Centre National de la Recherche Scientifique UA 040557), \\ Institut Pasteur, 75724 Paris Cedex 15, France
}

(Received 28 September 1987; revised 22 February 1988)

\begin{abstract}
A chromosomal DNA fragment from Bacillus alvei, encoding a thiol-dependent haemolytic product known as alveolysin $\left(M_{\mathrm{r}} 60000\right.$, pI 5.0) was cloned in Escherichia coli SK1592, using pBR322 as the vector plasmid. Only a single haemolysin-positive clone was identified, by testing for haemolysis on blood agar plates. The haemolytic material was associated with the host bacterial cell. It was released by ultrasonic disruption and purified 267 -fold. A $64 \mathrm{kDa}$ polypeptide of pI 8.2 cofractionated with haemolytic activity during gel filtration chromatography and isoelectric focusing. It behaved identically to alveolysin in its activation by thiols, inactivation by thiol group reagents, inhibition by cholesterol, and neutralization, immunoprecipitation and immunoblotting by immune sera raised against alveolysin and streptolysin $O$.
\end{abstract}

\section{INTRODUCTION}

Alveolysin is an extracellular, cytolytic and lethal single-chain protein toxin $\left(M_{\mathrm{r}} \sim 60000\right)$ identified as a haemolysin in the culture fluids of Bacillus alvei (Bernheimer \& Grushoff, 1967), a micro-organism isolated from soil and honey-bee larvae suffering from European foul brood (Katznelson \& Lochhead, 1947; Buissière \& Colobert, 1966). This toxin is a member of the group of thiol-activated (or SH-dependent) cytolysins, which comprises at least 16 biologically and antigenically related proteins produced by Gram-positive bacterial species belonging to the genera Streptococcus, Bacillus, Clostridium and Listeria (Smyth \& Duncan, 1978; Alouf, 1980; Alouf et al., 1986; Bernheimer, 1986). The prototype of these toxins is streptolysin O (SLO), produced by streptococci belonging to Lancefield groups A, C and G (Alouf, 1980; Bhakdi et al., 1984). The toxins damage eukaryotic cells by disruption of the cytoplasmic membrane and intracytoplasmic organelles (Smyth \& Duncan, 1978; Launay et al., 1984; Bremm et al., 1985). Alveolysin and the other SH-dependent toxins (Alouf et al., 1977; Geoffroy et al., 1981; Thelestam et al., 1981; Geoffroy \& Alouf, 1983) share common biochemical properties such as activation by thiols and inactivation by oxidation or interaction with $3 \beta$-hydroxysterols. Cholesterol is thought to be the toxin receptor and target at the surface of eukaryotic cells (Prigent \& Alouf, 1976; Cowell \& Bernheimer, 1978; Smyth \& Duncan, 1978; Alouf \& Geoffroy, 1984; Bernheimer, 1986). Cholesterol-containing artificial lipid membranes such as liposomes (Cowell \& Bernheimer, 1978; Alving et al., 1979; Geoffroy \& Alouf, 1983) or mixed lipid monolayers at air-water interfaces (Alouf et al., 1984; Blumenthal \& Habig, 1984) are disrupted or penetrated, or both, by the SH-dependent toxins.

As a step towards the elucidation of the structural and antigenic relatedness of $B$. alvei alveolysin to the six other SH-dependent toxins purified so far (Alouf et al., 1984, 1986; Parrisius et al., 1986; Geoffroy et al., 1987), the molecular cloning of the alveolysin determinant, its expression, and partial purification of the alveolysin-like product in Escherichia coli were

Abbreviations: HU, haemolytic unit; RH, recombinant haemolysin; SLO, streptolysin O. 
undertaken. A comparative study of some biochemical, toxic and immunological properties of $B$. alvei alveolysin and the recombinant protein expressed in $E$. coli is also described.

\section{METHODS}

Bacterial strains. Bacillus alvei strain ATCC 6344 (Pasteur Institute Collection) was used for the preparation of genomic DNA (Geoffroy \& Alouf, 1983). This strain produces large amounts of alveolysin (about 2500 haemolytic units, $\mathrm{HU}$, per $\mathrm{ml}$ of culture supernate, equivalent to $2.5 \mu \mathrm{g}$ protein $\mathrm{ml}^{-1}$ ). Escherichia coli strain SK 1592 (tonA gal thi $s b c B 15$ end A hsdR4 $h s d M^{+}$) (Rapoport et al., 1979) kindly provided by G. Rapoport and A. Klier (Pasteur Institute, Paris) was used as the recipient strain in transformation experiments.

Media and growth conditions. B. alvei was cultured overnight at $30^{\circ} \mathrm{C}$ with shaking in minimal medium containing (per litre) $6 \mathrm{~g} \mathrm{KH} \mathrm{KO}_{4}, 10.65 \mathrm{~g} \mathrm{~K}_{2} \mathrm{HPO}_{4} .2 \mathrm{~g}\left(\mathrm{NH}_{4}\right)_{2} \mathrm{SO}_{4}, 2 \mathrm{~g}$ sodium citrate. $5 \mathrm{H}_{2} \mathrm{O}, 0.4 \mathrm{~g}$ $\mathrm{MgSO}_{4} .7 \mathrm{H}_{2} \mathrm{O}$ supplemented with $1 \%(\mathrm{w} / \mathrm{v})$ proteose peptone no. $3($ Difco) and $2.5 \%(\mathrm{w} / \mathrm{v})$ glucose. E. coli was cultured at $37^{\circ} \mathrm{C}$ with shaking in L-broth (Davis et al., 1980) [1\%(w/v) Bactotryptone (Difco), $0.5 \%(w / v)$ yeast extract (Difco), $1 \%(\mathrm{w} / \mathrm{v}) \mathrm{NaCl}$, supplemented when necessary with ampicillin $\left.\left(100 \mu \mathrm{g} \mathrm{ml}^{-1}\right)\right]$. For agar plates, $15 \mathrm{~g}$ Bacto-agar (Difco) was added per litre of L-broth supplemented with either ampicillin $\left(100 \mu \mathrm{g} \mathrm{ml}^{-1}\right) \mathrm{or}^{\circ}$ tetracycline $\left(12.5 \mu \mathrm{g} \mathrm{ml}^{-1}\right)$ (Sigma). Blood agar plates contained $5 \%(\mathrm{v} / \mathrm{v})$ defibrinated sheep blood.

Alveolysin preparation. The toxin was purified as described by Geoffroy \& Alouf (1983). One HU corresponds to $1 \mathrm{ng}\left(1.66 \times 10^{-5} \mathrm{nmol}\right)$ protein.

Titration of haemolytic activity. The assay was based on the determination of the haemolytic activity of the toxin preparation (activated with $20 \mathrm{~mm}$-cysteine) as described previously (Geoffroy \& Alouf, 1983). Haemoglobin released from sheep erythrocytes $\left(6 \times 10^{8}\right.$ cells ml-1) incubated at $37^{\circ} \mathrm{C}$ with $1 \mathrm{ml}$ of appropriately diluted toxin in phosphate-buffered saline (PBS) pH $6.8\left(37 \mathrm{~mm}-\mathrm{NaH}_{2} \mathrm{PO}_{4}, 37 \mathrm{~mm}-\mathrm{Na}_{2} \mathrm{HPO}_{4}, 77 \mathrm{~mm}-\mathrm{NaCl}\right.$ ) was determined spectrophotometrically at $541 \mathrm{~nm}$. One $\mathrm{HU}$ is that amount of toxin needed to release $50 \%$ of the haemoglobin content of the erythrocytes. The incubation times for haemolytic assays were $45 \mathrm{~min}$ for alveolysin and $3 \mathrm{~h}$ for the haemolytic gene product expressed from plasmid pCG100, referred to as recombinant haemolysin (RH).

Preparation of B. alvei chromosomal DNA. DNA was prepared and purified according to G. Rapoport \& A. Klier (personal communication). Briefly, the bacterial pellet from an $800 \mathrm{ml}$ culture was suspended in $3 \mathrm{ml}$ Tris/EDTA/NaCl buffer pH $8.0(100 \mathrm{~mm}$-Tris/HCl pH 8.0, $10 \mathrm{~mm}$-EDTA, $150 \mathrm{~mm}-\mathrm{NaCl})$ and incubated for $10 \mathrm{~min}$ at $37^{\circ} \mathrm{C}$ with $1.6 \mathrm{mg}$ lysozyme (Sigma). The suspension was incubated for an additional $1 \mathrm{~h}$ at $37^{\circ} \mathrm{C}$ in the presence of $1.25 \mathrm{mg}$ pancreatic ribonuclease A (Sigma), dissolved in $1 \mathrm{ml}$ distilled water and heated at $80^{\circ} \mathrm{C}$ for $10 \mathrm{~min}$ prior to use. After addition of sodium dodecyl sulphate to $1 \%(\mathrm{w} / \mathrm{v})$, the mixture was incubated at $70^{\circ} \mathrm{C}$ for $15 \mathrm{~min}$ and then allowed to react for $1 \mathrm{~h}$ at $37^{\circ} \mathrm{C}$ with $40 \mathrm{mg}$ proteinase $\mathrm{K}$ (Boehringer). The lysate was dialysed overnight at $37^{\circ} \mathrm{C}$ and extracted twice with phenol/chloroform $(1: 1, \mathrm{v} / \mathrm{v})$ and DNA was then precipitated by addition of 2 vols absolute ethanol and $0 \cdot 1$ vol. $3 \mathrm{M}$-sodium acetate $\mathrm{pH} 4 \cdot 8$. After overnight incubation at $-20^{\circ} \mathrm{C}$, DNA was recovered, washed in $70 \%$ ethanol, dissolved in distilled water and stored at $-20{ }^{\circ} \mathrm{C}$.

Isolation of plasmid DNA. The vector plasmid pBR322 and its recombinant derivative (pCG100) were isolated from E. coli strain SK 1592 and purified according to Humphreys et al. (1975). The method of Birnboim \& Doly (1979) was used for rapid preparation of plasmid DNA.

DNA digestion with restriction enzymes. Restriction endonucleases were used as recommended by the manufacturers (Boehringer and New England Biolabs). The electrophoresis of DNA fragments was done in $0.8 \%$ (w/v) horizontal agarose gels using TBE buffer pH 8.0 (45 mM-Tris, 45 mM-boric acid, 1.25 mm-disodium EDTA). The agarose gels and running buffer contained $0.5 \mu \mathrm{g}$ ethidium bromide (Sigma) $\mathrm{ml}^{-1}$. Gels were photographed on a UV transilluminator (Vilbert Lourmat) with a Polaroid camera equipped with red and yellow filters, using type 665 Polaroid film.

Construction of hybrid plasmid and transformation. Purified B. alvei DNA $(3 \mu \mathrm{g})$ partially digested with HindIII $\left(2 \mathrm{~h}, 37^{\circ} \mathrm{C}\right)$ was added to $3 \mu \mathrm{g}$ of HindIII-digested pBR322. Ligation of DNA fragments $(10000-1000 \mathrm{bp})$ was done using T4 DNA ligase and standard procedures (Maniatis et al., 1982). The products of ligation were used to transform E. coli SK 1592 cells previously rendered competent (Bolivar et al., 1977). E. coli transformants were selected on either L-agar plates or blood agar plates containing appropriate antibiotics.

Ultrasonic disruption of transformed E. coli. Washed organisms from an overnight culture of $E$. coli carrying either pBR322 or its derivatives were resuspended in a 1/50 to 1/200 volume of PBS. The cell suspensions were subjected to ultrasonic disruption at $4{ }^{\circ} \mathrm{C}$ using a Branson Cell Disruptor B30 sonicator (Heat Systems Ultrasonic) fitted with a microtip operated at a setting of 7 . The cells were sonicated for $3 \times 10 \mathrm{~s}$ bursts and allowed to cool for $30 \mathrm{~s}$ between treatments. The suspension was centrifuged $\left(15 \mathrm{~min}, 10000 \mathrm{~g}, 4^{\circ} \mathrm{C}\right)$ and the supernate taken for the determination of haemolytic titre and other assays. This treatment was repeated up to six times on the same cell pellet to maximize recovery of haemolysin.

Nick-translation and Southern blot hybridization. Plasmid pCG100 DNA was labelled by nick-translation according to Rigby et al. (1977), with $\alpha-\left[{ }^{32} \mathrm{P}\right] \mathrm{dATP}$ and $\alpha-\left[{ }^{32} \mathrm{P}\right] \mathrm{dCTP}$ (NEN; $\left.400 \mathrm{Ci} \mathrm{mmol}^{-1}, 14 \cdot 8 \mathrm{TBq} \mathrm{mmol}^{-1}\right)$. 
Hybridization experiments were done as described by Southern (1975), using Schleicher and Schüll BA85 nitrocellulose filters. HindIII-digested chromosomal DNA isolated from Streptococcus pyogenes strain A78 (Alouf, 1980), Bacillus thuringiensis strain H1-30 (serotype 1), kindly provided by H. de Barjac (Institut Pasteur, Paris), Listeria monocytogenes strain EGD (Geoffroy et al., 1987) and Clostridium perfringens strain 5265 type C, kindly provided by M. Sebald (Institut Pasteur, Paris) were probed for hybridization.

Immune sera. Hyperimmune horse antistreptolysin O serum no. 525 (Alouf et al., 1965) and rabbit antialveolysin serum (Alouf et al., 1977) were used in neutralization, precipitation and immunoblotting experiments. Neutralizing titres of the sera were determined as described previously (Alouf et al., 1965).

Agarose double immunodiffusion. Immunodiffusion assays were done on glass slides in $1 \%(\mathrm{w} / \mathrm{v})$ agarose in PBS, $\mathrm{pH} 6.8$. Wells of $4 \mathrm{~mm}$ were cut in the agar gel and filled with appropriate antigens and sera. The distance between the wells was $6 \mathrm{~mm}$.

Purification of the recombinant haemolysin expressed in E. coli. The washed cell pellet from a 2-litre overnight culture was resuspended in $10 \mathrm{ml}$ buffer and submitted to ultrasonic disruption as described above. The disrupted cell suspension was immediately centrifuged $\left(15 \mathrm{~min}, 10000 \mathrm{~g}, 4^{\circ} \mathrm{C}\right)$ and the supernatant fraction collected. The pellet was resuspended in $5 \mathrm{ml}$ PBS and disrupted again. Six successive disruptions were made on the same pellet with decreasing amounts of buffer. The six supernatant fractions were combined (crude extract) and purified as follows.

Nucleic acids in the extract were precipitated by adding $10 \mathrm{mg}$ protamine sulphate (Sigma) $\mathrm{ml}^{-1}$ and removed by centrifugation $\left(15 \mathrm{~min}, 10000 \mathrm{~g}, 4^{\circ} \mathrm{C}\right.$ ). The supernate was concentrated by ultrafiltration through an Amicon PM-10 membrane and subjected to gel filtration on a Sephacryl S-200 column (Pharmacia) $(2.5$ by $100 \mathrm{~cm}$ ) equilibrated in PBS, pH 6.8 (flow rate $10 \mathrm{ml} \mathrm{h}^{-1}, 3.5 \mathrm{ml}$ fractions). The eluted haemolytic material was recovered in two peaks, corresponding to elution volumes of $300-390 \mathrm{ml}$ and $390-600 \mathrm{ml}$ respectively. About $60 \%$ of the haemolytic activity was recovered in the second peak at the same elution volume as that of alveolysin (Geoffroy \& Alouf, 1983).

The second peak pool was concentrated by ultrafiltration (fraction $\mathrm{P} 2$ ) and electrofocused $\left(16 \mathrm{~h}, 2^{\circ} \mathrm{C}, 1600 \mathrm{~V}\right)$ in a $110 \mathrm{ml}$ column (LKB) using a pH 3.5-10 sucrose gradient as described previously (Loridan \& Alouf, 1986). The column content was collected ( $1 \mathrm{ml}$ fractions) and monitored for $\mathrm{pH}\left(4^{\circ} \mathrm{C}\right), A_{280}$ and haemolytic titre. The haemolytic material focused in two peaks at $\mathrm{pH} 8 \cdot 1$ and $8 \cdot 3$, which were pooled and concentrated.

Inhibition of haemolytic activity by thiol group reagents and cholesterol. Haemolysin samples (alveolysin or $\mathrm{RH}$ ) in a volume of $900 \mu \mathrm{l}(25 \mathrm{HU})$ were incubated at room temperature for $30 \mathrm{~min}$ with $100 \mu \mathrm{l}$ of appropriate dilutions of $\mathrm{HgCl}_{2}, p$-chloromercuribenzoate, tosyl-lysine chloromethylketone (TLCK) dissolved in PBS, pH 6.8, and tosylphenylmethylketone (TPCK) (Geoffroy \& Alouf, 1982), epicholesterol or cholesterol dissolved in double-distilled absolute ethanol (Geoffroy \& Alouf, 1983). All reagents were from Sigma. The mixtures were brought to a final volume of $5 \mathrm{ml}$ with PBS and their residual haemolytic activity determined. The results were expressed as the amount of reagent required to inhibit the lytic activity of $1 \mathrm{HU}$ of toxin.

Neutralization by immune sera. Samples of alveolysin or RH ( $2 \mathrm{HU})$ were allowed to react with appropriate dilutions of rabbit anti-alveolysin serum and horse anti-SLO serum in a final volume of $1 \mathrm{ml}$ as described by Alouf et al. (1965). The results were expressed as the amounts (in $\mu$ l) of immune serum required to inhibit the lytic activity of $1 \mathrm{HU}$ of toxin.

Protein assay. Protein was determined on crude and purified fractions by the method of Bradford (1976), using the Bio-Rad protein assay kit with bovine serum albumin (Sigma) as a standard.

Slab SDS-PAGE and immunoblotting. Slab SDS-polyacrylamide gradient gel electrophoresis was done according to Laemmli (1970). Protein samples $(20-50 \mu \mathrm{l})$ containing $2 \%(\mathrm{w} / \mathrm{v})$ SDS, $10 \%(\mathrm{v} / \mathrm{v})$ glycerol and $5 \%(\mathrm{v} / \mathrm{v})$ 2-mercaptoethanol in 62.5 mM-Tris/ $\mathrm{HCl}$ buffer, $\mathrm{pH} \mathrm{6.8,} \mathrm{were} \mathrm{boiled} \mathrm{in} \mathrm{a} \mathrm{water} \mathrm{bath} \mathrm{for} 90 \mathrm{~s}$ before being loaded on the gels. Electrophoresis was done in a linear gradient of $7 \cdot 5-25 \%(\mathrm{w} / \mathrm{v})$ acrylamide at $5 \mathrm{~mA}$ for about $15 \mathrm{~h}$ until the tracking dye $(0.001 \%$ bromophenol blue) reached the bottom of the gel. After electrophoresis, the separated proteins were detected by staining with $0 \cdot 2 \%$ Coomassie brilliant blue R-250 in methanol/water/glacial acetic acid ( $5: 4: 1$, by vol.).

For Western blot analysis (Towbin et al., 1979) the proteins were electrophoretically transferred to nitrocellulose sheets (BA85, Schleicher \& Schüll) in a Trans-Blot cell apparatus (EMBL, Heidelberg, FRG) with $25 \mathrm{mM}$ Tris $/ 200$ mM-glycine ( $\mathrm{pH} 8.4) / 20 \%$ (v/v) methanol as the blotting buffer. The sheets were incubated for $1 \mathrm{~h}$ at room temperature with shaking in $50 \mathrm{mM}-\mathrm{Tris} / \mathrm{HCl}, 150 \mathrm{mM}-\mathrm{NaCl}(\mathrm{pH} 8.0)$ and $5 \%(\mathrm{w} / \mathrm{v})$ skim milk (Regilait, France) prior to a $1 \mathrm{~h}$ incubation in anti-alveolysin or antistreptolysin immune sera diluted $(1: 20)$ in the above buffer. The sheets were washed eight times in buffer before addition of $20 \mathrm{ml}$ milk buffer containing $1 \mu \mathrm{Ci}(37 \mathrm{kBq})$

${ }^{125}$ I-labelled protein A kindly prepared by N. Guiso (Institut Pasteur, Paris). Shaking was continued for a further $1 \mathrm{~h}$ and then the filters were washed six times in buffer supplemented with $0 \cdot 1 \%$ Triton X-100. The filters were dried for $30 \mathrm{~min}$ at $80^{\circ} \mathrm{C}$ and then autoradiographed using Kodak X-O-Mat (SO-282) film.

Preparation of membrane-bound haemolysins and analytical procedures. The standard erythrocyte suspension $\left(6 \times 10^{8}\right.$ cells ml-1) in PBS, pH 6.8, was incubated $\left(500 \mu l, 30 \mathrm{~min}, 37^{\circ} \mathrm{C}\right)$ with either $50 \mu \mathrm{l}$ alveolysin $(10000 \mathrm{HU}$, 
$10 \mu \mathrm{g}$ ) or $100 \mu \mathrm{l} \mathrm{RH}$ preparation $(\sim 10000 \mathrm{HU}, 170 \mu \mathrm{g})$. After complete lysis, the membranes were sedimented by centrifugation at $15000 \mathrm{~g}$ for $10 \mathrm{~min}$ at $4{ }^{\circ} \mathrm{C}$ and the supernate was discarded. The ghosts were then washed twice in PBS, suspended in $50 \mu \mathrm{l}$ of the same buffer and incubated overnight with $\alpha$-chymotrypsin (Worthington) at a final concentration of $200 \mu \mathrm{g} \mathrm{ml}^{-1}$. Membrane-associated proteins were then analysed by SDS-PAGE $(\sim 100 \mu \mathrm{g}$ per lane) as described above.

Lethal activity. Specific-pathogen-free male ICR Swiss mice (Charles River), 6 to 8 weeks old, were used. The mice were injected intravenously with $0.5 \mathrm{ml}$ PBS containing various amounts $(2500,1500,1000,750,650 \mathrm{HU})$ of alveolysin or of the purified RH. The lethality was recorded $1 \mathrm{~h}$ after injection since, at dose levels which killed only some of the animals, death generally occurred within minutes or the animals survived (Alouf, 1980). The 50\% lethal dose $\left(\mathrm{LD}_{50}\right)$ was determined by the probit method. Control injections consisted of $0.5 \mathrm{ml}$ (13 mg protein) of the supernate generated following sonication of $E$. coli SK 1592 harbouring pBR322.

\section{RESULTS}

Cloning of alveolysin in E. coli

A gene library of $B$. alvei total genomic DNA was constructed in $E$. coli using pBR322 as the cloning vector. HindIII-generated partial digest products of $B$. alvei DNA were ligated with

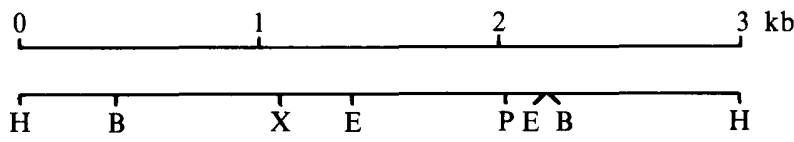

Fig. 1. Restriction map of the insert from the recombinant plasmid pCG100 containing the $B$. alvei alveolysin determinant studied in $E$. coli SK1592. Restriction enzyme cleavage sites: B, BamHI, E, EcoRI, H, HindIII, P, PstI, X, XbaI. No restriction sites were found with ClaI, KpnI, PvuII or SmaI.

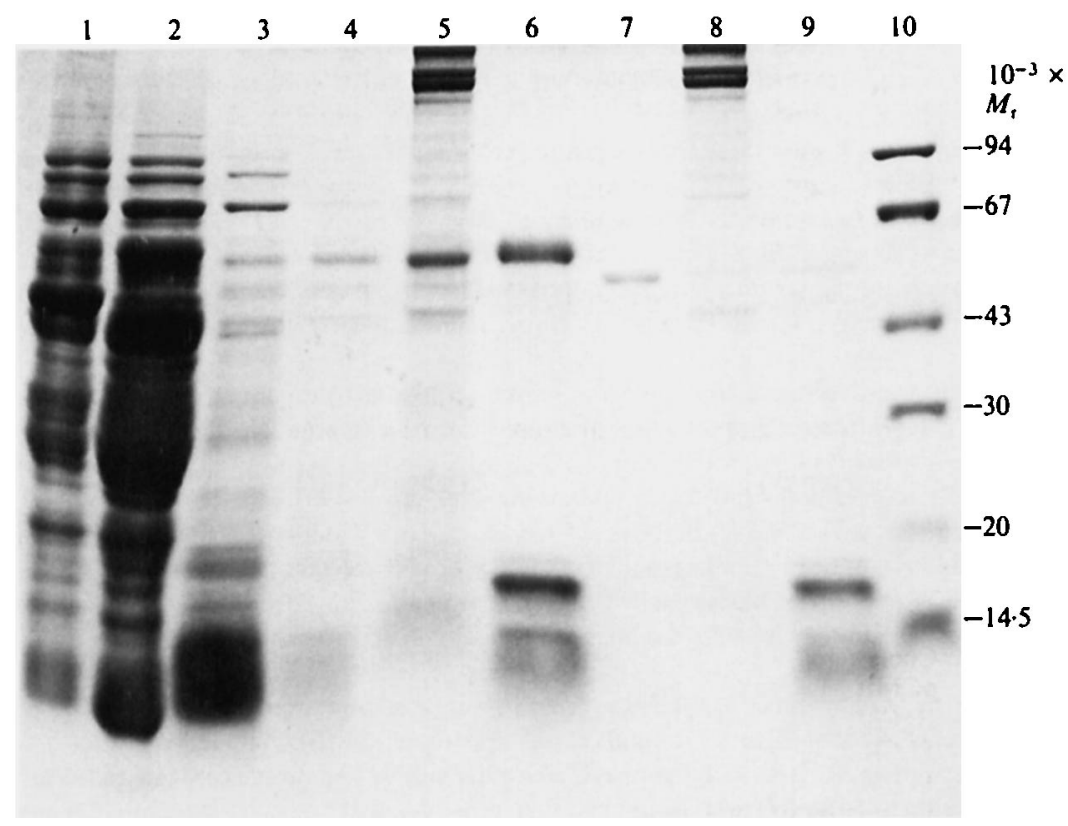

Fig. 2. SDS-PAGE of purification fractions (Table 1) and of sheep erythrocyte ghosts obtained by lysis with alveolysin and RH. Lanes: 1, crude extract; 2, protamine-precipitated fraction (P1); 3, concentrated fraction from Sephacryl S-200 gel filtration (P2); 4, pooled haemolytic material (RH) after isoelectric focusing (P3): 5, sheep erythrocyte ghosts after lysis with $\mathrm{RH}$; 6, same as lane 5, after chymotrypsin digestion; 7 , purified alveolysin; 8 , sheep erythrocyte ghosts after lysis with alveolysin; 9 , same as lane 8 , after chymotrypsin digestion; $10, M_{\mathrm{r}}$ standards (Pharmacia 'it) - phosphorylase $b$ $(94000)$, bovine serum albumin (67000), ovalbumin (43000), carbonic anhydrase (30000), soybean trypsin inhibitor (20000), $\alpha$-lactalbumin (14500). 
HindIII-cleaved vector, and the ligated mixture was used to transform E. coli SK1592. Transformants were selected on L-agar and recombinant clones identified by their sensitivity to tetracycline. Of 3000 transformants examined, $360(12 \%)$ were tetracycline sensitive. One haemolytic clone was identified among these following transfer of the transformants onto sheep blood agar, as evidenced by the formation after $24 \mathrm{~h}$ of a small zone of complete haemolysis ( $3 \mathrm{~mm}$ in diameter) around the colony. The recombinant plasmid pCG100 was isolated from this positive clone and purified by $\mathrm{CsCl}$ gradient centrifugation.

The recombinant plasmid was about $7.3 \mathrm{~kb}$ in size, with an insertion of about $3 \mathrm{~kb}$. A restriction map of the DNA insert from $B$. alvei was constructed by a series of double enzyme digestions (Fig. 1). The analysis identified two BamHI, two EcoRI, one $X b a \mathrm{I}$ and one Pst I sites, whereas no restriction sites were found with $K p n I$, PvuII, ClaI and SmaI.

The $3 \mathrm{~kb}$ DNA fragment labelled by nick-translation was used as a probe in Southern hybridization analysis of HindIII-digested chromosomal DNA isolated from $S$. pyogenes, L. monocytogenes, $B$. thuringiensis and $C$. perfringens strains, under hybridization conditions at a stringency of about $80 \%$. No homology was detected.

\section{Expression of alveolysin in E. coli}

E. coli SK 1592 harbouring pCG 100 gave rise to colonies surrounded by a $3 \mathrm{~mm}$ haemolytic zone after $24 \mathrm{~h}$ of incubation. An identical pattern was exhibited by $B$. alvei colonies under the same conditions. No haemolytic zones developed with $E$. coli SK 1592 harbouring pBR322 only. When the transformed $E$. coli cells were allowed to grow in the agar layer, the zones of haemolysis were larger and developed earlier than those obtained with surface-grown organisms. E. coli SK 1592 harbouring pCG 100 showed no detectable haemolytic material in the culture supernatant fraction when cultured with or without shaking in L-broth at $37^{\circ} \mathrm{C}$ for up to

Table 1. Purification of recombinant haemolysin from E. coli SK1592

\begin{tabular}{lcccccc}
\multicolumn{1}{c}{ Step* } & $\begin{array}{c}\text { Vol. } \\
(\mathrm{ml})\end{array}$ & $\begin{array}{c}\text { Total } \\
\text { protein } \\
(\mathrm{mg})\end{array}$ & $\begin{array}{c}\text { Total } \\
\text { haemolytic } \\
\text { activity (HU) }\end{array}$ & $\begin{array}{c}\text { Specific } \\
\text { activity } \\
\text { [HU (mg protein) }\end{array}$ & $\begin{array}{c}\text { Purification } \\
\text { (-fold) }\end{array}$ & $\begin{array}{c}\text { Recovery } \\
(\%)\end{array}$ \\
Crude extract & 34 & 882 & 165000 & 187 & 1 & 100 \\
P1 & 12 & 492 & 150000 & 304 & 1.6 & 90 \\
P2 & 4 & 11.6 & 100000 & 8620 & 47 & 60 \\
P3 & 4 & 1.7 & 85000 & 50000 & 267 & 51
\end{tabular}

* P1, protamine sulphate purification; P2, gel filtration on Sephacryl S-200; P3, isoelectric focusing in a broad pH gradient.

Table 2. Comparative properties of alveolysin and cloned haemolysin $(R H)$

\begin{tabular}{lcc}
\multicolumn{1}{c}{ Property } & Alveolysin & RH \\
pI & $5 \cdot 0$ & $8 \cdot 1-8 \cdot 3$ \\
$M_{\mathrm{r}}$ & 60000 & 64000 \\
Haemolytic activity* $^{*}$ & + & + \\
Inhibitors $\left(\mu \mathrm{mol} \mathrm{HU}^{-1}\right) \dagger$ & $10^{-8}$ & \\
$\quad$ Cholesterol & 1 & $10^{-5}$ \\
pCMB & 1 & 1 \\
$\mathrm{HgCl}_{2}$ & 1 & 1 \\
TLCK & 2 & 1 \\
TPCK & & 2 \\
Inhibition by immune sera & 2 & 10 \\
$\quad$ Anti-alveolysin $(\mu \mathrm{l})$ & $0 \cdot 1$ & $0 \cdot 3$ \\
Anti-streptolysin O ( $\mu \mathrm{l})$ & 300 & 1000 \\
Lethal activity $\mathrm{LD}_{50}$ (in $\left.\mathrm{HU}\right)$ & &
\end{tabular}

\footnotetext{
* Tested on horse, rabbit and sheep erythrocytes as described in Methods.

† Amount of reagent required to inhibit the lytic activity of $1 \mathrm{HU}$ of toxin. pCMB, p-chloromercuribenzoate; TLCK, tosyl-lysine chloromethylketone; TPCK, tosyl-phenylmethylketone.

$\ddagger$ Amounts in microlitres of immune sera required to inhibit the lytic activity of $1 \mathrm{HU}$ of toxin.
} 
$18 \mathrm{~h}$. Furthermore, the bacterial pellet suspended in PBS was not haemolytic. However, when the cell pellet from an overnight culture was submitted to ultrasonic disruption followed by centrifugation at $10000 \mathrm{~g}$ for $10 \mathrm{~min}$, the cells released a haemolytic product into the suspending buffer. This material was subsequently identified as an alveolysin-like product (see below) with a titre of about $150 \mathrm{HU}\left(\mathrm{mg}\right.$ protein) ${ }^{-1}$. E. coli SK 1592 harbouring pBR322 yielded under the same conditions a weakly active haemolytic material with a titre of about $10 \mathrm{HU}$ (mg protein $)^{-1}$.

\section{Purification and identification of the recombinant haemolysin}

The purification process summarized in Table 1 yielded fraction 3, referred to as the recombinant haemolysin material $(\mathrm{RH})$. The specific activity of this fraction was 267 -fold higher than that of crude material.

The various fractions (Table 1) were analysed by SDS-PAGE (Fig. 2). The RH preparation exhibited a major band $\left(M_{\mathrm{r}} 64000\right)$ and several minor bands.

\section{Comparative properties of alveolysin and recombinant haemolysin}

These properties are summarized in Table 2. The haemolytic titres of the two preparations were practically identical when tested on horse, rabbit, and sheep erythrocytes. Their lytic activities were inhibited by the same concentrations of thiol group reagents, TPCK and TLCK, as previously described for alveolysin (Geoffroy et al., 1981). As expected, cholesterol inhibited the lytic activity of both products, at concentrations of $4 \times 10^{-3} \mathrm{ng} \mathrm{HU}^{-1}$ and $4 \mathrm{ng} \mathrm{HU}^{-1}$ for alveolysin and $\mathrm{RH}$ respectively. No inhibition with epicholesterol $\left(400 \mathrm{ng} \mathrm{HU}^{-1}\right)$ was observed.

The RH and purified alveolysin preparations proved to be antigenically related. Immune sera raised against alveolysin and SLO were used to probe both preparations by immunoblotting (Fig. $3 a, b$ ). The haemolytic activity of these preparations was neutralized by the two sera. However, about three- to five-fold higher amounts of sera were required to neutralize $1 \mathrm{HU}$ of RH as compared to alveolysin. Both haemolytic preparations showed total antigenic identity by agar double immunodiffusion against equine anti-SLO serum (data not shown).

The lytic process with $\mathrm{RH}$ was much slower $(3 \mathrm{~h}$ for $100 \%$ lysis of the haemolytic system by $2 \mathrm{HU}$ ) as compared to alveolysin $(45 \mathrm{~min})$. Sheep erythrocyte ghosts resulting from lysis by either haemolysin showed a similar pattern on SDS-PAGE (Fig. 2). Both haemolysins were detected by immunoblotting at positions corresponding to their respective $M_{\mathrm{r}}$ values of 60000 for alveolysin and 64000 for RH (Fig. $3 a, b$ ). This finding suggests that RH binds to target cells and elicits lysis (Fig. 2, lane 5) in the same way as alveolysin (Fig. 2, lane 8) and other SHdependent toxins.

When bound to sheep erythrocyte ghosts, both alveolysin and RH were resistant to enzymic digestion by $\alpha$-chymotrypsin (Fig. 2, lanes 6,9 ), whereas in solution, both haemolysins were totally degraded (data not shown).

The $\mathrm{LD}_{50}$ of RH was about $1000 \mathrm{HU}$, as compared to $300 \mathrm{HU}$ for alveolysin (Table 2). Death occurred within less than $5 \mathrm{~min}$ and the symptoms (convulsions, opisthotonos) were identical to those observed with alveolysin, SLO and listeriolysin O (Alouf, 1980; Geoffroy et al., 1987). Control mice injected with supernatant material from sonicated $E$. coli SK 1592 bearing pBR322 died after $24 \mathrm{~h}$, probably due to LPS toxicity.

\section{DISCUSSION}

The antigenic, biochemical and biological similarity of the thiol-activated bacterial cytolysins is well documented (see Introduction). The understanding of the mode of action of these toxins requires knowledge of their structure. The first $29 \mathrm{~N}$-terminal amino acid residues of alveolysin have been determined (Alouf et al., 1986). Apparent homology between this sequence and that of shorter $\mathrm{N}$-terminal sequences of other related toxins has been observed (Alouf et al., 1986). The best approach for the determination of the amino acid sequences of these proteins would be that inferred from the nucleotide sequence of their structural genes. The genes encoding SLO (Kehoe \& Timmis, 1984), pneumolysin from Streptococcus pneumoniae (Paton et al., 1986; Walker et al., 1987) and listeriolysin O from Listeria monocytogenes (Mengaud et al., 1987, 1988) 


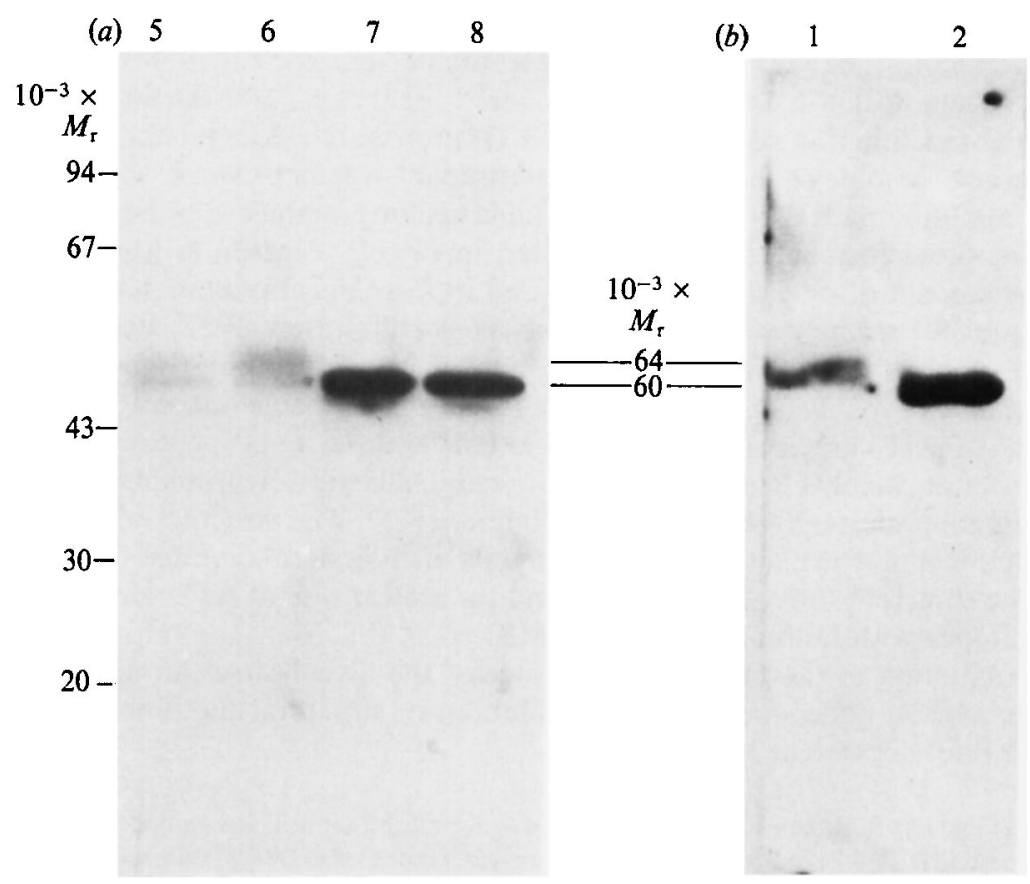

Fig. 3. Western immunoblots of sheep erythrocyte ghosts obtained by lysis with alveolysin and RH. (a) Lanes 5 to 8 of Fig. 2 tested with rabbit anti-alveolysin immune serum,; (b) RH (lane 1) and purified alveolysin (lane 2) tested with equine antistreptolysin $\mathrm{O}$ immune serum.

have been cloned and expressed in $E$. coli, and the nucleotide sequences of the cloned pneumolysin (Walker et al., 1987), SLO (Kehoe et al., 1987) and listeriolysin O (Mengaud et al., 1988) genes have been determined.

Striking homologies at the protein level between these three toxins have been inferred from these determinations. The region of strongest homology was in the C-terminal end. The longest continuous identical sequence consisted of 12 residues encompassing the single Cys residue close to the C-termini of the molecules. However, when the cloned genes were used as probes no detectable homologies were observed at the DNA level (Kehoe \& Timmis, 1984; Kehoe et al., 1987; Mengaud et al., 1987, 1988). It has been suggested that these genes have originated from a common evolutionary source but have undergone considerable divergence (Kehoe et al., 1987).

In the present work, hybridization experiments with the cloned alveolysin determinant also failed to detect homology between this determinant and DNA from $C$. perfringens, $L$. monocytogenes, $S$. pyogenes and $B$. thuringiensis strains expressing high levels of their respective immunologically related thiol-dependent toxins.

The recombinant plasmid was stably maintained in E. coli SK 1592 and directed the synthesis of a haemolysin exhibiting characteristics of alveolysin, namely (i) haemolytic activity and binding to target cells; (ii) specific inhibition of the haemolytic activity by cholesterol but not by epicholesterol; (iii) inhibition by thiol group reagents as well as TPCK and TLCK; (iv) neutralization, immunoblotting and immunoprecipitation by immune sera raised against alveolysin or SLO; (v) lethal activity in mice.

The recombinant haemolysin was not secreted from $E$. coli and required ultrasonic disruption for release. Thus either $B$. alvei possesses a protein-secretory apparatus that is lacking in $E$. coli or the alveolysin secretory signal is not recognized by the $E$. coli apparatus. A similar situation has been reported for the genes of the three above-mentioned cytolysins, as was also observed when cloned genes for haemolytic toxins and other extracellular toxins or enzymes from a number of Gram-positive and Gram-negative bacterial species were introduced into $E$. coli (Coleman et al., 1983; Kehoe et al., 1983; Chakraborty et al., 1986; Guidolin \& Manning, 1987). 
The low amount (4\%) of $\mathrm{RH}$ expressed in E. coli compared to that secreted by B. alvei (Geoffroy \& Alouf, 1983) may be attributable to the impairment of toxin processing and transport in its new host, to a degradative turnover inside the cell, or to the likelihood that Grampositive promoters function poorly if at all in a Gram-negative background. It is also possible that the native promoter of the alveolysin determinant was not cloned or functioning in the $E$. coli host, and that the RH was expressed from a vector promoter. Similar low yields of toxin have been reported for cholera toxin expressed in E. coli (Pearson \& Mekalanos, 1982). In contrast, the amount of pneumolysin synthesized in $E$. coli is approximately one-third of that which accumulates in the cytoplasm of $S$. pneumoniae (Johnson, 1977; Paton et al., 1986).

The RH expressed in $E$. coli differed in $M_{\mathrm{r}}$ and $\mathrm{pI}$ from alveolysin (Figs 2 and 3, Table 2), suggesting that it probably corresponds to the alveolysin molecule linked to its signal peptide. The basic pI of RH is consistent with this notion because signal peptides of most secreted proteins have a positively charged $\mathrm{N}$-terminal region, a central hydrophobic core, and a more polar C-terminal region (Oliver, 1985; von Heijne, 1985). The structural differences between alveolysin and RH may explain the higher amounts of cholesterol required for the inhibition of the latter, the threefold lower $\mathrm{LD}_{50}$ of $\mathrm{RH}$ and the slower rate of lysis. However, RH shared common epitopes with both alveolysin and SLO.

The determination of the nucleotide sequence of the alveolysin determinant will certainly contribute to a better understanding of the evolutionary, structural and functional relationships between the thiol-dependent toxins.

We are grateful to Drs F. Rakotobé, G. Rapoport and A. Klier for their help and guidance in the construction of the gene bank and to P. Berche for toxicity tests. We are greatly indebted to Dr G. Boulnois and J. Walker for their experimental contribution in the improvement of the restriction map and for constructive suggestions and critical review of the manuscript. We thank Dr S. Warren for helpful criticism, and L. Cayrol for secretarial assistance.

\section{REFERENCES}

Alouf, J. E. (1980). Streptococcal toxins: streptolysin O, streptolysin S, erythrogenic toxins. Pharmacology and Therapeutics 11, 661-717.

Alouf, J. E. \& GeOFFroY, C. (1984). Structure activity relationships in sulfhydryl-activated toxins. In Bacterial Protein Toxins, pp.165-171. Edited by J. E. Alouf, F. J. Fehrenbach, J. H. Freer \& J. Jeljaszewicz. London: Academic Press.

Alouf, J. E., Viette, M., Corvazier, R. \& Raynaud, M. (1965). Préparation et propriétés de sérums de chevaux anti-streptolysine $\mathrm{O}$. Annales de l'Institut Pasteur 108, 476-500.

Alouf, J. E., Kiredjian, M. \& Geoffroy, C. (1977). Purification de l'hémolysine thiol-dépendante extracellulaire de Bacillus alvei. Biochimie 59, 329336.

Alouf, J. E., Geoffroy, C., Pattus, F. \& Verger, R. (1984). Surface properties of bacterial sulfhydrylactivated cytolytic toxins. Interaction with monomolecular films of phosphatidylcholine and various sterols. European Journal of Biochemistry 141, 205-210.

Alouf, J. E., Geoffroy, C., Gilles, A. M. \& FALMAGNe, P. (1986). Structural relatedness between five bacterial sulfhydryl activated toxins: streptolysin $\mathrm{O}$, perfringolysin $\mathrm{O}$, alveolysin, pneumolysin and thuringiolysin. In Bacterial Protein Toxins, pp. 49-50. Edited by P. Falmagne, J. E. Alouf, F. J. Fehrenbach, J. Jeljaszewicz \& $\mathbf{M}$. Thelestam. Stuttgart: Gustav Fischer Verlag.

Alving, C. R., Habig, W. H., Urban, K. A. \& HaRdegree, M. C. (1979). Cholesterol-dependent tetanolysin damage to liposomes. Biochimica et biophysica acta 551, 224-228.

BERNHEIMER, A. W. (1986). Interactions between membranes and cytolytic peptides. Biochimica et biophysica acta 864, 123-141.

Bernheimer, A. W. \& Grushoff, P. (1967). Extracellular hemolysins of aerobic sporogenic bacilli. Journal of Bacteriology 93, 1541-1543.

Bhakdi, S., Roth, M., Sziegoleit, Z. \& TranumJENSEN, J. (1984). Isolation and identification of two hemolytic forms of streptolysin $\mathrm{O}$. Infection and Immunity 46, 394-400.

BiRnBoIM, H. C. \& Doly, J. (1979). A rapid alkaline extraction procedure for screening recombinant plasmid DNA. Nucleic Acids Research 7, 1514-1523.

Blumenthal, R. \& HABIG, W. G. (1984). Mechanism of tetanolysin-induced membrane damage: studies with black lipid membranes. Journal of Bacteriology 157, 321-323.

Bolivar, F., Rodriguez, R. L., Greene, P. J., BetlaCh, M. L., HEYNECKER, H. L., BOYER, H. W. Crosa, J. H. \& Falkow, S. (1977). Construction and characterisation of new cloning vehicles. II. A multipurpose cloning system. Gene 2, 95-113.

BuISSIÈRE, J. \& COLOBERT, L. (1966). Influence de l'état lysogène des colonies, les caractères biochimiques et pathogènes de Bacillus alvei. Comptes rendus de l'Académie des Sciences D263, 570-572.

BRADFORD, M. M. (1976). A rapid and sensitive method for the quantitation of microgram quantities of protein, utilizing the principle of protein-dye binding. Analytical Biochemistry 72, 248-257. 
Bremm, K. D., Konig, W., Pfeiffer, P., Rauschen, I., Theobald, K., Thelestam, M. \& Alouf, J. E. (1985). Effect of thiol-activated toxins (streptolysin $O$, alveolysin and theta-toxin) on the generation of leukotriene-inducing and -metabolizing enzymes from human polymorphonuclear granulocytes. Infection and Immunity 50, 844-851.

Chakraborty, T., Huhle, B., Bergbauer, H. \& GOEBEL, W. (1986). Cloning, expression and mapping of the Aeromonas hydrophila aerolysin gene determinant in Escherichia coli K12. Journal of Bacteriology 167, 368-374.

Coleman, K., Dougan, G. \& Arbuthnott, J. P. (1983). Cloning and expression in Escherichia coli K12 of the chromosomal hemolysin (phospholipase C) determinant of Pseudomonas aeruginosa. Journal of Bacteriology 153, 909-915.

Cowell, J. L. \& Bernheimer, A. W. (1978). Role of cholesterol in the action of cereolysin on membranes. Archives of Biochemistry and Biophysics 190, 603-610.

Davis, R. W., Botstein, D. \& Roth, J. R. (1980). Advanced Bacterial Genetics. Cold Spring Harbor, NY: Cold Spring Harbor Laboratory.

Geoffroy, C. \& Alouf, J. E. (1982). Interaction of alveolysin, a sulfhydryl-activated bacterial cytolytic toxin, with thiol group reagents and cholesterol. Toxicon 20, 239-241.

Geoffroy, C. \& Alouf, J. E. (1983). Selective purification by thiol-disulfide interchange chromatography of alveolysin, a sulfhydryl-activated toxin of Bacillus alvei. Journal of Biological Chemistry 258, 9968-9972.

Geoffroy, C., Gilles, A.-M. \& Alouf, J. E. (1981). The sulfhydryl groups of the thiol-dependent cytolytic toxin from Bacillus alvei. Evidence for one essential sulfhydryl group. Biochemical and Biophysical Research Communications 99, 781-788.

Geoffroy, C., Gaillard, J. L., Alouf, J. E. \& BERCHE, P. (1987). Purification, characterization and toxicity of the sulfhydryl-activated hemolysin (listeriolysin O) from Listeria monocytogenes. Infection and Immunity 55, 1641-1646.

Guidolin, A. \& Manning, P. A. (1987). Genetics of Vibrio cholerae and its bacteriophages. Microbiological Reviews 51, 285-298.

voN HeisNe, G. (1985). Signal sequences. The limits of variation. Journal of Molecular Biology 184, 99-105.

Humphreys, G. O., Willshaw, G. A. \& Anderson, E. S. (1975). A simple method for the preparation of large quantities of pure plasmid DNA. Biochimica et biophysica acta 383, 457-463.

Johnson, M. K. (1977). Cellular location of pneumolysin. FEMS Microbiology Letters 2, 243-245.

KATZNELSON, H. \& LoChHEAD, A. G. (1947). Nutrition requirements of Bacillus alvei and Bacillus para-alvei. Journal of Bacteriology 53, 83-88.

KeHOE, M. \& TIMmis, K. (1984). Cloning and expression in Escherichia coli of the streptolysin O determinant from Streptococcus pyogenes: characterization of the cloned streptolysin $O$ determinant and determination of the absence of substantial homology with determinants of other thiol-activated toxins. Infection and Immunity 43, 804-810.

Kehoe, M., Duncan, J., Foster, T., Fairweather, N. \& DunCaN, C. (1983). Cloning, expression, and mapping of the Staphylococcus aureus alpha-hemolysin determinant in Escherichia coli $\mathrm{K}-12$. Infection and Immunity 41, 1105-1111.

Kehoe, M. A., Miller, L., Walker, J. A. \& BoulnoIS, G. J. (1987). Nucleotide sequence of the streptolysin O (SLO) gene: structural-homologies between SLO and other membrane-damaging thiolactivated toxins. Infection and Immunity 55, 3228-3232.

LAEMMLI, U. K. (1970). Cleavage of structural proteins during the assembly of the head of bacteriophage T4. Nature, London 227, 680-685.

Launay, J.-M., Geoffroy, C., Costa, J. L. \& Alouf, J. E. (1984). Purified SH-activated toxins (streptoly$\sin \mathrm{O}$, alveolysin): new tools for determination of platelet enzyme activities. Thrombosis Research 33, 189-196.

LoRIDAN, C. \& Alouf, J. E. (1986). Purification of RNA-core induced streptolysin $\mathrm{S}$ and isolation and haemolytic characteristics of the carrier-free toxin. Journal of General Microbiology 132, 307-315.

Maniatis, T., Fritsch, E. F. \& Sambrook, J. (1982). Molecular Cloning, a Laboratory Manual. Cold Spring Harbor, NY: Cold Spring Harbor Laboratory.

Mengaud, J., Chenevert, J. Geoffroy, C., GailLARD, J.-L. \& COSSART, P. (1987). Identification of the structural gene encoding the SH-activated hemolysin of Listeria monocytogenes: listeriolysin $\mathrm{O}$ is homologous to streptolysin $O$ and pneumolysin. Infection and Immunity 55, 3225-3227.

Mengaud, J., Vicente, M. F., Chenevert, J., Moniz Pereira, J., Geoffroy, C., Gicquel-Sanzey, B., Baquero, F., Perez-Diaz. J.-C. \& Cossart, P. (1988). Expression in Escherichia coli and sequence analysis of the listeriolysin $\mathrm{O}$ determinant of Listeria monocytogenes. Infection and Immunity 56, 766-772. OlIVER, D. (1985). Protein secretion in Escherichia coli. Annual Review of Microbiology 39, 615-648.

Parrisius, J., Bhakdi, S., Roth, M., Tranum-Jensen, J., Goebel, W. \& Seeliger, H. P. R. (1986). Production of listeriolysin by beta-hemolytic strains of Listeria monocytogenes. Infection and Immunity 51, 314-319.

Paton, J. C., Berry, A. M., Lock, R. A., Hansman, D. \& Manning, P. A. (1986). Cloning and expression in Escherichia coli of the Streptococcus pneumoniae gene encoding pneumolysin. Infection and Immunity 54, 50-55.

Pearson, G. D. \& Mekalanos, J. J. (1982). Molecular cloning of Vibrio cholerae enterotoxin genes in Escherichia coli K-12. Proceedings of the National Academy of Sciences of the United States of America 79, 2976-2980.

Prigent, D. \& Alouf, J. E. (1976). Interaction of streptolysin O with sterols. Biochimica et biophysica acta 443, 288-300.

Rapoport, G. R., Klier, A., Billault, A., Fargette, F. \& DEDONDER, R. (1979). Construction of a colony bank of $E$. coli containing hybrid plasmids representative of the Bacillus subtilis 168 genome. Molecular and General Genetics 176, 239-245.

Rigby, D. W. J., Dieckman, M., Rhodes, C. \& Berg, P. (1977). Labelling deoxyribonucleic acid to high specific activity in vitro by nick translation with DNA polymerase. Journal of Molecular Biology 113, 237-251. 
Smyth, C. J. \& Duncan, J. L. (1978). Thiol-activated (oxygen-labile) cytolysins. In Bacterial Toxins and Cell Membranes, pp. 129-183. Edited by J. Jeljaszewicz \& T. Wadström. New York: Academic Press.

SoUTHERN, E. M. (1975). Detection of specific sequences among DNA fragments separated by gel electrophoresis. Journal of Molecular Biology 98, 503-517.

Thelestam, M., Alouf, J. E., Geoffroy, C. \& MollBy, R. (1981). Membrane-damaging action of alveolysin from Bacillus alvei. Infection and Immunity 32, 1187-1192.
Towbin, H., Staehelin, T. \& Gordon, J. (1979). Electrophoretic transfer of proteins from polyacrylamide gels to nitrocellulose sheets: procedure and some applications. Proceedings of the National Academy of Sciences of the United States of America 76, 4350-4354.

Walker, J. A., Allen, R. L., Falmagne, P., Johnson, M. K. \& BoulNoIS, G. J. (1987). Molecular cloning, characterization of complete nucleotide sequence of the gene for pneumolysin, the sulfhydryl-activated toxin of Streptococcus pneumoniae. Infection and Immunity 55, 1184-1189. 